\title{
Conceptualising Climate change in Forest Based Rural Communities of South Africa: Community Perceptions and Attitudes
}

\author{
C. Ofoegbu ${ }^{1 *}$, P. W. Chirwa ${ }^{1}$, J. Francis ${ }^{2}$ and F. D. Babalola ${ }^{3}$ \\ ${ }^{1}$ Forest Science Postgraduate Programme, University of Pretoria, 5-15 Plant Sciences Complex, Pretoria, \\ South Africa \\ ${ }^{2}$ Institutes for Rural Development, University of Venda, Thohoyandou 0950, South Africa \\ ${ }^{3}$ Department of Forest Resources Management,University of Ilorin, Ilorin, Nigeria \\ *Tel: +2710909153; Email: ofoegbu.c@gmail.com.
}

\section{SUMMARY}

The perceptions of forest-based communities in Vhembe District of South Africa were examined. Special attention in this study was paid to the following aspects of climate change: socio-cultural issues, views and awareness, beliefs with respect to causes, concerns and lifestyle adjustments people are prepared to make in order to adapt. Vegetation type was used as criterion to select Makhado, Mutale and Thulamela Municipalities, which together with Musina constitute Vhembe District. Seven rural communities in each municipality were selected. Using the stratified proportionate random sampling procedure in combination with weighted Enumeration Area (EA) for the selected communities, 366 households were chosen and interviewed. It was found that although awareness of the specific term climate change was poor, most respondents possessed good knowledge of it and associated challenges. Increasing frequencies of erratic rainfall and forest fires were said to be visible manifestations of climate change. There was also a strong concern about the effects of climate change on forests and related products. The respondents expressed the desire to adopt responsible behaviour towards use and management of forests as a climate change intervention strategy. However, most community members were sceptical about the causes of climate change. Taking all these issues into account, there is need for activities that would enlighten the people on the causes and consequences of climate change with respect to their livelihood. This would help promote awareness of climate change and people's participation in crafting measures that slow down climate change.

Keywords: Climate change; climate variability; perceptions; forest, rural community 


\section{INTRODUCTION}

The growing consensus among scientists that climate change is happening and will continue to do so into the future (Christensen et al. 2007), is placing debate on it on the spotlight of social research over the last two decades (Wolfsegger 2005; National Planning Commission; NDC 2011). There is increasing interest and concern about how observed and predicted changes in climate patterns will affect society and natural ecosystems (Wolfsegger 2005; NPC 2011). In South Africa, debate on climate change is increasing. Apparently, this has been a result of the observed increase in annual temperatures in the country of about $0.13^{\circ} \mathrm{C}$ per decade between 1960 and 2003 and predicted decrease of approximately $5.4 \%$ by 2020 (Turpie and Visser 2013). Furthermore, Gandure et al. (2013) predicted that climate variability and extremes in South Africa were likely to increase and become more frequent in the future. Consequently, climate change is expected to have serious environmental, economic, and social impacts on South Africa's rural households (Gbetibouo 2009). Regardless of how scientists perceive climate change, individual perceptions of its meaning are likely to relate more to the public discourse and wider debate about the extent of its impact on human and natural systems (Rick et al. 2008; Weingart et al. 2000). Understandings of public values are therefore required for shaping people's engagement with climate change, and minimising risks inherent in climate communication (Corner et al 2014; Wolf and Moser 2011)

Wiid and Ziervogel (2012) noted that the effectiveness with which a community responds to the challenge of climate change depends on how well individual members understand it. Thus, understanding how climate change and variability are experienced and interpreted at rural community level is crucial (Wiid and Ziervogel 2012). The growing awareness that scientific knowledge on the causes and impact of climate change is becoming inadequate in designing appropriate intervention measures is promoting this assertion (Nesha 
et al. 2014). Both the Intergovernmental Panel on Climate Change (IPCC 2007) and Ishaya and Abaje (2008) concurred that investigations based solely on climate change projections using empirical models fail to capture the micro-level specificities of local communities. Similarly, Piya et al. (2012) reported that these models fail to predict climate phenomena at local scale and only few of them integrate socioeconomic variables which are relevant to rural communities and policy makers.

Most studies on public perception of climate change in South Africa, as in most African countries, have focused on understanding people's perceptions and awareness of it (Turpie et al. 2002; Gandure et al. 2013; Turpie and Visser 2013). They do not address the concerns and attitudes that might affect livelihood activities (Marsden et al. 2009) and climate change intervention initiatives. Bryan et al. (2009) conducted studies in South Africa and Ethiopia, which revealed the importance of people's perceptions in understanding the role of education and creating awareness of adaptation options among farmers. Maddison (2007) reported that farmers from many African countries perceived that temperature had increased and rains less predictable, in addition to being received for shorter periods. Macharia et al. (2011) reported that farmers in Nyeri North and Laikipia East Districts of Kenya identified destruction of natural resources, in particular indigenous trees, as a major contributor to climate change in the region. In Senegal, Mertz et al. (2009) observed that farmers were aware of climate change and identified wind and occasional excessive rainfall as the most significant factors that needed attention when adaptation measures are developed. In Nigeria, Ishaya and Abaje (2008) revealed that farmers perceived climate change to have occurred over the years due to diverse human activities.

In contrast to the situation in South Africa, some empirical studies that focused on the relationship between rural people's perceptions and understanding of climate change were conducted in some parts of the world. As a result, there is limited understanding of this issue 
in the country. In addition to this, not much is known about the attitudes of the people towards forest based livelihood activities such as exploitation and management of forest resource. The rural population makes up about $40 \%$ of South Africa's population. Moreover, most of these people mainly depend on forests, forest products and subsistence farming (Chamberlain et al. 2005; Turpie and Visser 2013; Vhembe District 2013; Ofoegbu 2014). An understanding of the attitudes of rural households living adjacent to forest towards climate change is therefore essential for crafting robust intervention measures. Understanding the attitude of the rural people as well as their perception of climate change is pertinent to promoting sustainable practices in forest exploitation and management operations. Therefore, it is not surprising that questions on how rural people in South Africa perceive and interpret climate change are of interest to social scientists and policy makers (Turpie et al. 2002).

Research into rural community perceptions and understanding of climate change help improve communication on the scientific discourse of climate change, influence positive behavioural change and better inform policy makers (Buys et al. 2012). This sheds light on conceptualisation of climate change in rural forest-based communities of South Africa. The forest sector often plays a pivotal role in policies aimed at adaptation and mitigation of the effects of climate change (Ishaya and Abaje 2008; Piya et al. 2012; Dube and Phiri 2013). It is, therefore, important to specifically examine attitudes and perceptions of forest-dependent people residing in rural areas regarding climate change. In order to achieve this, the following research questions were used as a guide in a study carried out in Vhembe District of South Africa:

1. What are the people's perceptions of climatic events and ultimately climate change?

2. What are the peoples' concerns about effects of climate change on livelihood?

3. What are the people's beliefs and perceptions about the causes of climate change?

4. How do the people obtain information about climate change? 
5. Is there any association between beliefs about causes of climate change and willingness to adopt intervention measures for climate change?

The concept, climate change, was used in a broad context that included changes in variability and extreme weather events. It was specifically designed to examine the ways in which households understood climate change in forest-based rural communities.

\section{METHODOLOGY}

Although climate change perception data can be collected using focus group discussions, a questionnaire survey was conducted because of its amenability to statistical analysis and tracking change over time. The questionnaire design was based on a year-long literature study, reconnaissance survey and consultations with community leadership and other relevant stakeholders.

\section{Description of Study Area}

As reported earlier, the study was conducted in Vhembe District Municipality of Limpopo province in the Republic of South Africa $\left(22^{\circ} 56 \mathrm{~S}, 30^{\circ} 28 \mathrm{E}\right)$ as shown in Figure 1 . Vhembe is one of the five Districts that make Limpopo Province. The District has a total population of $1199886,54.4 \%$ of them being females. Approximately, half $(48.72 \%)$ of the people in Vhembe District reside in Thulamela local Municipality. The rest of the population is distributed as follows: Makhado (41.43\%), Mutale (6.58\%), and Musina (3.28\%), (STATSA 2012). The main languages spoken are Tshivenda (69\%) and Xitsonga (27\%). 


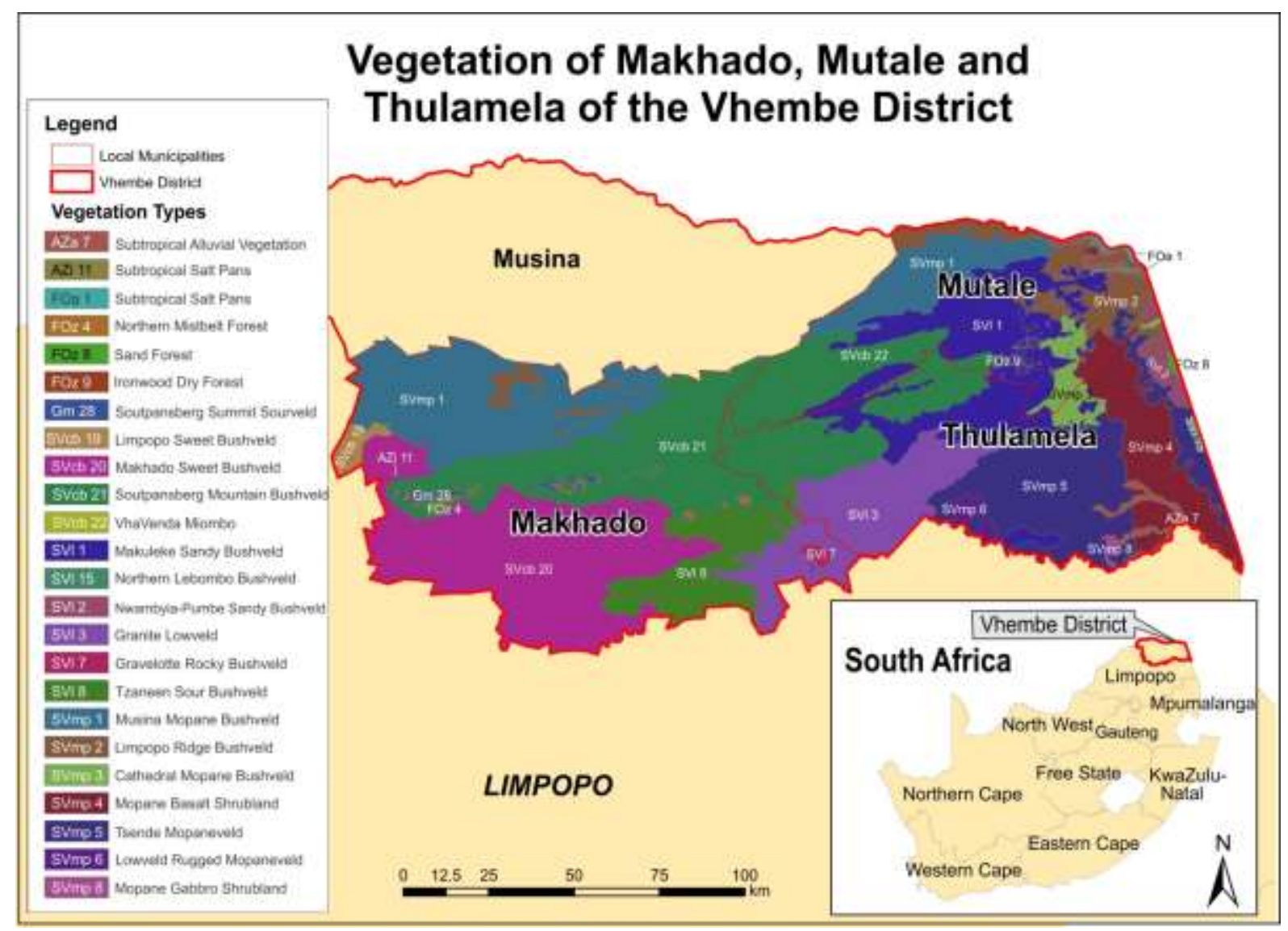

FIGURE 1 Vegetation map of Vhembe District of South Africa

\section{Questionnaire survey and Sampling procedure}

Makhado, Musina, Mutale and Thulamela local municipalities constitute Vhembe District. In order to cover the various representations of forest and forest based livelihood in the district, vegetation type and dominant livelihood strategy were the criteria considered when selecting Makhado, Mutale and Thulamela Municipalities for this study. In each of these Municipalities, seven rural communities were selected. This gave a combined total of 21 rural communities that made up the study area. Using the stratified proportionate random sampling procedure, 366 households were then selected to serve as respondents. The purposive sampling technique was applied to select respondents in the households who were eventually interviewed using a questionnaire. Only those members of the households who were more 
than 20 years old and had lived for more than five years in their communities were sampled. A questionnaire was administered to them, individually.

The questionnaire contained both open and closed-ended questions. The questionnaire was pretested and adjusted to suit the situation in the field. It was designed to explore households' understanding, awareness, beliefs about causes, concerns about effects on their forest-based livelihoods, and willing behavioural change regarding sustainable forest management in the context of climate change.

A research leader and eight enumerators administered the questionnaire. The enumerators were selected based on their academic qualifications, as well as experience in the subject matter and conducting surveys using structured questionnaires. Given the strategic need to ensure that the study questions were communicated to respondents in their mother tongue for accurate understanding as per Swanepoel and Beer (2006) recommendation, the study questionnaire was translated into the two dominant local languages (Tshivenda and Xitsonga). The translated questionnaire was then pre-tested to ensure its accuracy. Results of the pre-test were used to make final corrections to the questionnaire. Prior to the pre-test, a workshop was organised for the selected field enumerators. They were orientated on the study objectives and trained on how to administer the questionnaire. After the workshop, a pilot survey was carried out to enable the enumerators to familiarise with the questionnaire prior to its actual administration. Following the approach pattern used by Ham and Theron (2001), the local chiefs and headsmen in the studied rural communities in Vhembe District were first visited and briefed about the study. Permission to carry out the research was obtained several months before the actual data collection. 


\section{Statistical analysis}

Primary data collected through the questionnaire were entered into the computer and stored as a Microsoft Excel spread sheet. The weighting adjustment technique was applied to correct for possible problems of either over- or under-representation of variables (Bethlehem 2015). The sample was weighed against the actual population to arrive at the weighted sample. Thereafter, the weighted data were imported into the Statistical Package for Social Sciences (SPSS) version 23.0. Data analysis involved computing frequencies and conducting the Chisquare and binomial tests, in addition to logistic regression analysis in relation to the study objective and research questions.

The binomial test was used to test the significance of yes and no responses with respect to observed ecosystem indicators of climate change (Berg 2014). The Pearson's Chisquare and Bonferoni tests were used to analyse associations between beliefs about causes of climate change and the willingness to accept responsible attitudes to forest utilization and management; and association between concern about climate change and willingness to accept responsible attitude to forest utilization and management (Clewer and Scarisbrick 2001). The Pearson Chi-square was used where the expected cell frequency was $\geq 5$, while Maximum-Likelihood (M-L) Chi-square was adopted when the expected cell frequencies were lower than five (Turyahabwe et al. 2006). Logistic regression was used to determine the factors that drove the perceptions of climate variability and change, and beliefs about causes of climate change (Harrell 2001). A p-value of $p<0.05$ represented statistical significance in hypothesis testing and $95 \%$ confidence intervals were used to describe the estimation of unknown parameters (Clewer and Scarisbrick 2001).

\section{Specification of the logistic regression model}

The standard binomial Logit regression model with dichotomous, categorical dependent 
variables was specified. In order to model perception of variability in climate, the dependent variable was "perceive" and "does not perceive". With respect to modelling beliefs in causes of climate change, the target variables were placed in the following belief groups: anthropogenic causes, cultural/spiritual causes, and climate change is a natural phenomenon.

The list of possible explanatory variables used in the models included (1) households and household head $(\mathrm{HH})$ characteristics: employment status (yes 1; no $=0$ ), farming skill (yes 1; no $=0$ ), livestock keeping skill (yes 1; no =0), carpentry skill (yes 1; no =0), academic qualification (yes 1 ; no $=0)$, years of residency in the community categorised as; $(\leq$ 38) (yes 1; no =0), (39-52) (yes 1; no =0), (53-65) (yes 1; no =0), $(66+)($ yes 1 ; no $=0)$, and age of respondent categorised as $(\leq 38)($ yes 1 ; no $=0),(39-52)$ (yes 1 ; no $=0),(53-65)$ (yes 1 ; no $=0),(66+)($ yes 1 ; no $=0)$. The Chi-square test at 0.05 significance level was used to assess the goodness of fit of the models.

\section{RESULTS}

\section{Awareness of the term climate change}

As revealed in Figure 2, awareness of climate change was generally poor in Mutale (74. 3\%) and Makhado (67.3\%). However, in Thulamela only $14.9 \%$ of the respondents reported that they had never heard of climate change. Furthermore, the Pearson Chi-Square test showed that there was a significant difference $(\mathrm{p}=0.000)$ in climate change awareness among the three municipalities. The Bonferoni test confirmed that although the level of awareness of climate was the same in Makhado and Musina, the residents of Thulamela were significantly more aware of it $(\mathrm{P}<0.001)$ than in the former Municipalities. 


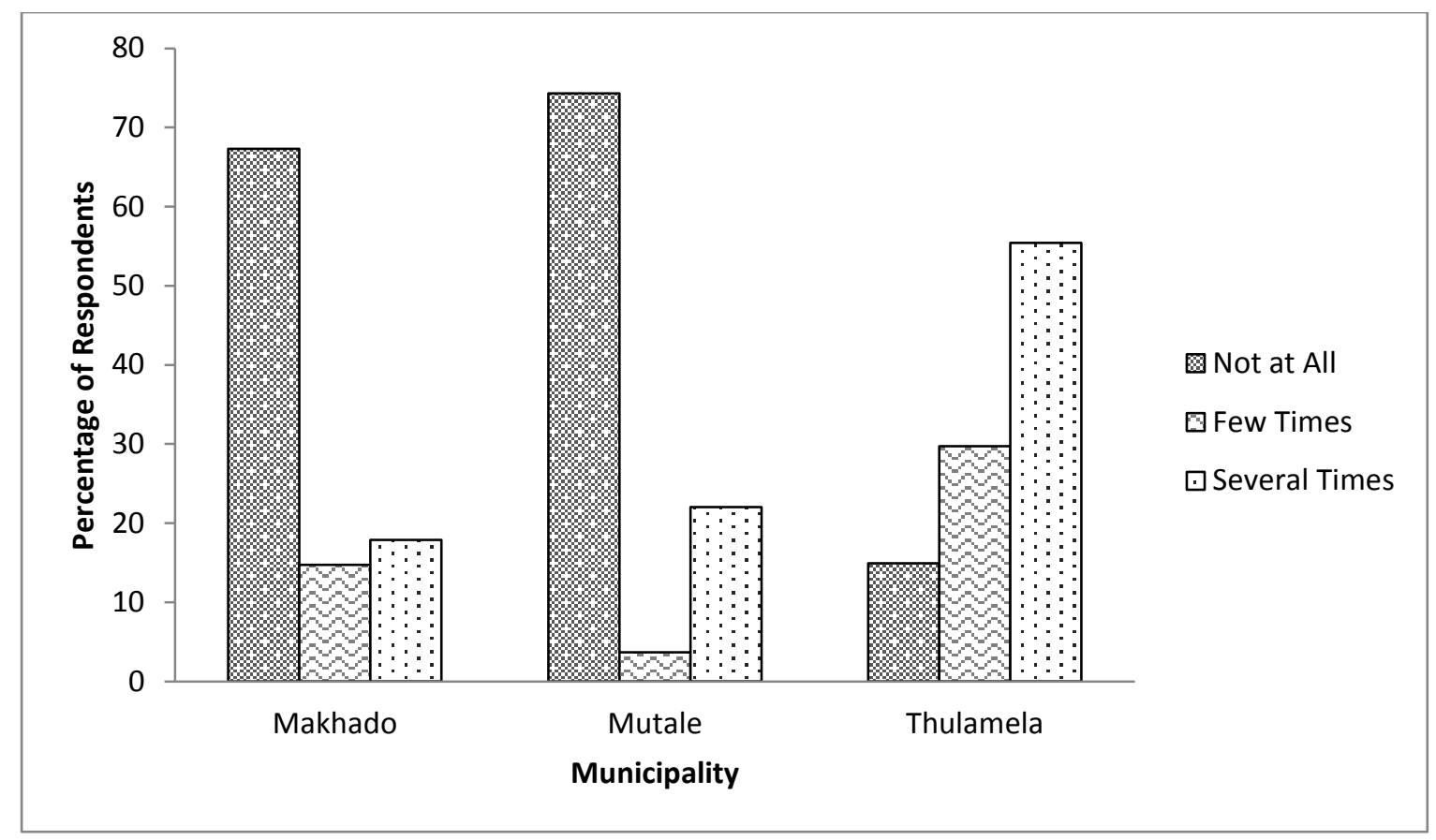

FIGURE 2 Respondent's awareness of the specific term climate change in the study communities

\section{Perception of variability in climatic events and seasons}

Even though there was a poor awareness of "climate change" in most of the studied communities, a high level of perception of changes in climatic events was observed in this study. More than half of the respondents (see Table 1) in Thulamela (58\%), Makhado $(59.2 \%)$ and Mutale (70\%) highlighted that there was increased variability in rainfall pattern. There was no difference in this phenomenon across the Municipalities ( $p>0.05)$. About $74 \%$ of the respondents in Thulamela, $75.8 \%$ in Makhado and $85.3 \%$ in Mutale revealed that there was an increase in the occurrence of incidence of extreme temperatures. However, observed variation in extreme temperature, extreme wind, and serious drought were found to differ significantly $(\mathrm{p}<0.05)$ across the three municipalities. 
TABLE 1 Perceptions of rural people on changes in climatic events

\begin{tabular}{|c|c|c|c|c|c|}
\hline \multirow[t]{2}{*}{ Climatic event } & \multirow[t]{2}{*}{ Response } & \multicolumn{4}{|c|}{ Proportion of respondents $(\%)$ in } \\
\hline & & $\begin{array}{l}\text { Makhado } \\
(n=156)\end{array}$ & $\begin{array}{l}\text { Mutale } \\
\text { 156) }\end{array}$ & $(\mathbf{n}=$ & $\begin{array}{l}\text { Thulamela } \\
(n=156)\end{array}$ \\
\hline \multirow[t]{2}{*}{ Erratic rainfall } & Increasing & $59.2^{\mathrm{a}}$ & $70.0^{\mathrm{a}}$ & & $58.0^{\mathrm{a}}$ \\
\hline & $\begin{array}{l}\text { Decreasing } \\
\text { No change }\end{array}$ & $\begin{array}{l}29.9^{\mathrm{a}} \\
10.8^{\mathrm{a}}\end{array}$ & $\begin{array}{l}22.7^{\mathrm{b}} \\
7.3^{\mathrm{a}}\end{array}$ & & $\begin{array}{l}36.0^{\mathrm{c}} \\
6.0^{\mathrm{a}}\end{array}$ \\
\hline Extreme temperature & $\begin{array}{l}\text { Increasing } \\
\text { Decreasing } \\
\text { No change }\end{array}$ & $\begin{array}{l}75.8^{\mathrm{a}} \\
20.4^{\mathrm{a}} \\
3.8^{\mathrm{a}}\end{array}$ & $\begin{array}{l}85.3^{\mathrm{a}} \\
13.8^{\mathrm{a}} \\
0.9^{\mathrm{a}}\end{array}$ & & $\begin{array}{l}74.0^{\mathrm{a}} \\
12.0^{\mathrm{a}} \\
14.0^{\mathrm{b}}\end{array}$ \\
\hline Extreme wind & $\begin{array}{l}\text { Increasing } \\
\text { Decreasing } \\
\text { No change }\end{array}$ & $\begin{array}{l}47.8^{\mathrm{a}} \\
40.1^{\mathrm{a}} \\
12.1^{\mathrm{a}}\end{array}$ & $\begin{array}{l}64.2^{\mathrm{b}} \\
20.2^{\mathrm{b}} \\
15.6^{\mathrm{a}, \mathrm{b}}\end{array}$ & & $\begin{array}{l}41.4^{\mathrm{a}} \\
34.3^{\mathrm{a}, \mathrm{b}} \\
24.2^{\mathrm{b}}\end{array}$ \\
\hline Serious drought & $\begin{array}{l}\text { Increasing } \\
\text { Decreasing } \\
\text { No change }\end{array}$ & $\begin{array}{l}51.6^{\mathrm{a}} \\
36.3^{\mathrm{a}} \\
12.1^{\mathrm{a}, \mathrm{b}}\end{array}$ & $\begin{array}{l}72.5^{\mathrm{b}} \\
20.2^{\mathrm{b}} \\
7.3^{\mathrm{b}}\end{array}$ & & $\begin{array}{l}27.3^{\mathrm{c}} \\
51.5^{\mathrm{c}} \\
21.2^{\mathrm{a}}\end{array}$ \\
\hline
\end{tabular}

Each subscript letter denotes a subset of "Makhado, Mutale and Thulamela" categories whose row proportions do not differ significantly from each other at the 0.05 level

Aside from perception of variability in climatic events, respondents also perceived changes in onset and offset of seasons. Result in Table 2 shows proportion of respondents in Makhado (57.1\%), Mutale (71.6\%), and Thulamela (62.4\%) that perceived early onset of summer seasons. Fewer proportions of respondents also perceived either delayed onset or no change

TABLE 2 Perceptions of rural people on changes in onset and offset of seasons

\begin{tabular}{|c|c|c|c|c|}
\hline \multirow[t]{2}{*}{ Season } & \multirow[t]{2}{*}{ Response } & \multicolumn{3}{|c|}{ Proportion of respondents $(\%)$ in } \\
\hline & & $\begin{array}{l}\text { Makhado (n } \\
=156)\end{array}$ & $\begin{array}{l}\text { Makhado }(\mathrm{n}= \\
156)\end{array}$ & Makhado $(n=156)$ \\
\hline \multirow[t]{2}{*}{ Summer } & Comes early & $57.1^{\mathrm{a}}$ & $71.6^{\mathrm{b}}$ & $62.4^{\mathrm{a}, \mathrm{b}}$ \\
\hline & $\begin{array}{l}\text { Delays } \\
\text { No change }\end{array}$ & $\begin{array}{l}27.6^{\mathrm{a}} \\
15.4^{\mathrm{a}}\end{array}$ & $\begin{array}{l}19.3^{\mathrm{a}} \\
9.2^{\mathrm{a}}\end{array}$ & $\begin{array}{l}25.7^{\mathrm{a}} \\
11.9^{\mathrm{a}}\end{array}$ \\
\hline \multirow[t]{2}{*}{ Winter } & Comes early & $36.3^{\mathrm{a}}$ & $41.3^{\mathrm{a}}$ & $44.0^{\mathrm{a}}$ \\
\hline & $\begin{array}{l}\text { Delays } \\
\text { No change }\end{array}$ & $\begin{array}{l}43.3^{\mathrm{a}} \\
20.4^{\mathrm{a}}\end{array}$ & $\begin{array}{l}49.5^{\mathrm{a}} \\
9.2^{\mathrm{b}}\end{array}$ & $\begin{array}{l}34.0^{\mathrm{a}} \\
22.0^{\mathrm{a}}\end{array}$ \\
\hline \multirow[t]{2}{*}{ Spring } & Comes early & $30.8^{\mathrm{a}}$ & $21.1^{\mathrm{a}}$ & $29.0^{\mathrm{a}}$ \\
\hline & $\begin{array}{l}\text { Delays } \\
\text { No change }\end{array}$ & $\begin{array}{l}44.2^{\mathrm{a}} \\
25.0^{\mathrm{a}}\end{array}$ & $\begin{array}{l}73.4^{\mathrm{b}} \\
5.5^{\mathrm{b}}\end{array}$ & $\begin{array}{l}53.0^{\mathrm{a}} \\
18.0^{\mathrm{a}}\end{array}$ \\
\hline
\end{tabular}


in summer seasons. Furthermore, Pearson chi-square test indicate that there is no significant difference $(\mathrm{p}=0.196)$ in perceived variation in summer season across the municipalities. However, perceptions of variability in winter and spring seasons was found to be significantly different $(\mathrm{P}<0.05)$ across the municipalities.

We then used stepwise logit model to examine factors influencing perception of changes in climate variability and change. Among the predictor variables that were tested, shows that "having no qualification" and "farming skills" were the significant influencing factors that met the 0.05 significance level for entry and stay in the model (Table 3 ).

TABLE 3 Factors influencing respondents' perception of climate variability and change

\begin{tabular}{lccccc}
\hline \multicolumn{7}{c}{ Analysis of Maximum Likelihood Estimates } \\
\hline Parameter & DF & Estimate & $\begin{array}{l}\text { Standard } \\
\text { Error }\end{array}$ & $\begin{array}{l}\text { Wald } \\
\text { Chi-Square }\end{array}$ & \\
\hline Intercept & 1 & 1.6378 & 0.1571 & 108.6284 & $<.0001$ \\
\hline $\begin{array}{l}\text { No } \\
\text { Qualification }\end{array}$ & 1 & -0.4245 & 0.1589 & 7.1363 & 0.0076 \\
\hline Farming & 1 & 0.4123 & 0.1419 & 8.4480 & 0.0037 \\
\hline
\end{tabular}

Having no qualification decreases the likelihood that a respondent will perceive variability in climate and extreme weather event by 0.425 . This is likely because people without qualification are most likely to be illiterate and would therefore be limited in their ability to access information on climate variability and change from available media source in their locality. In contrast, possession of farming skill increases the likelihood that a respondent will perceive variability in climate and extreme weather event by 0.412 . 


\section{Awareness of specific indicators of climate change}

Evidence from literatures suggests that changes in ecosystems such as increase in frequency of incidence of pests, changes in crop ripening seasons, among others can be linked to impacts of climate change (Kadir et al. 2013). We consequently investigate respondents' awareness of changes in ecosystem in their locality as a probable indicator of climate change. Results in Table 4 show respondents' observations of ecosystem indicators of climate change in their locality.

TABLE 4 Indicators of climate change

\begin{tabular}{|c|c|c|c|c|}
\hline \multirow[t]{2}{*}{ Ecosystem indicators } & \multirow[t]{2}{*}{ Response } & \multicolumn{3}{|c|}{ Community } \\
\hline & & Makhado & Mutale & Thulamela \\
\hline \multirow[t]{4}{*}{ New plant species seen } & Yes & $48.1 \%$ & $64.2 \%$ & $63.0 \%$ \\
\hline & No & $42.9 \%$ & $30.3 \%$ & $32 \%$ \\
\hline & Don't know & $9.0 \%$ & $5.5 \%$ & $5.0 \%$ \\
\hline & Binomial test & ns & $* * *$ & $* *$ \\
\hline \multirow{4}{*}{$\begin{array}{l}\text { New diseases in } \\
\text { agricultural/tree crops }\end{array}$} & Yes & $55.1 \%$ & $72.5 \%$ & $58.0 \%$ \\
\hline & No & $28.8 \%$ & $16.5 \%$ & $33.0 \%$ \\
\hline & Don't know & $16.0 \%$ & $11.0 \%$ & $9.0 \%$ \\
\hline & Binomial test & $* *$ & $* * *$ & $*$ \\
\hline \multirow{4}{*}{$\begin{array}{l}\text { Increased frequency of } \\
\text { incidence of pests }\end{array}$} & Yes & $61.8 \%$ & $86.2 \%$ & $66.0 \%$ \\
\hline & No & $15.9 \%$ & $2.8 \%$ & $22.0 \%$ \\
\hline & Don't know & $22.3 \%$ & $11.0 \%$ & $12.0 \%$ \\
\hline & Binomial test & $* * *$ & $* * *$ & $* * *$ \\
\hline \multirow{4}{*}{$\begin{array}{l}\text { Changes in crop ripening } \\
\text { season }\end{array}$} & Yes & $73.7 \%$ & $61.5 \%$ & $52.0 \%$ \\
\hline & No & $19.2 \%$ & $20.2 \%$ & $38.0 \%$ \\
\hline & Don't know & $7.1 \%$ & $18.3 \%$ & $10.0 \%$ \\
\hline & Binomial test & $* * *$ & $* * *$ & ns \\
\hline \multirow{4}{*}{$\begin{array}{l}\text { Changes in flowering and } \\
\text { fruiting time }\end{array}$} & Yes & $77.1 \%$ & $64.2 \%$ & $55.0 \%$ \\
\hline & No & $16.6 \%$ & $19.3 \%$ & $40.0 \%$ \\
\hline & Don't know & $6.4 \%$ & $16.5 \%$ & $5.0 \%$ \\
\hline & Binomial test & $* * *$ & $* * *$ & ns \\
\hline \multirow[t]{4}{*}{ Changes in planting season } & Yes & $84.6 \%$ & $60.6 \%$ & $57.4 \%$ \\
\hline & No & $12.2 \%$ & $22.9 \%$ & $38.6 \%$ \\
\hline & Don't know & $3.2 \%$ & $16.5 \%$ & $4.0 \%$ \\
\hline & Binomial test & $* * *$ & $* * *$ & $*$ \\
\hline \multirow{4}{*}{$\begin{array}{l}\text { Frequency of bush fire is } \\
\text { increasing }\end{array}$} & Yes & $87.2 \%$ & $52.3 \%$ & $38.6 \%$ \\
\hline & No & $9.0 \%$ & $24.8 \%$ & $52.5 \%$ \\
\hline & Don't know & $3.8 \%$ & $22.9 \%$ & $8.9 \%$ \\
\hline & Binomial test & $* * *$ & $* *$ & ns \\
\hline Extinct of some plant species & Yes & $76.4 \%$ & $85.3 \%$ & $62.0 \%$ \\
\hline
\end{tabular}




\begin{tabular}{|c|c|c|c|c|}
\hline & No & $16.6 \%$ & $8.3 \%$ & $30.0 \%$ \\
\hline & Don't know & $7.0 \%$ & $6.4 \%$ & $8.0 \%$ \\
\hline & Binomial test & $* * *$ & $* * *$ & $* * *$ \\
\hline \multirow{4}{*}{$\begin{array}{l}\text { Water source and availability is } \\
\text { becoming scarce }\end{array}$} & Yes & $75.0 \%$ & $93.6 \%$ & $62.0 \%$ \\
\hline & No & $23.7 \%$ & $3.7 \%$ & $38.0 \%$ \\
\hline & Don't know & $1.3 \%$ & $2.8 \%$ & $0.0 \%$ \\
\hline & Binomial test & $* * *$ & $* * *$ & $*$ \\
\hline \multirow[t]{4}{*}{ Increased death of livestock } & Yes & $86.6 \%$ & $93.6 \%$ & $63.0 \%$ \\
\hline & No & $9.6 \%$ & $3.7 \%$ & $25.0 \%$ \\
\hline & Don't know & $3.8 \%$ & $2.8 \%$ & $12.0 \%$ \\
\hline & Binomial test & $* * *$ & $* * *$ & $* * *$ \\
\hline
\end{tabular}

There was a high level of perception in ecosystem indicators of climate change tested. However, not all observed indicators are significant for all municipalities. Observation of new plant species was not significant for Makhado. Likewise, observations of changes in crop ripening season, and changes in flowering and fruiting time was not significant for Thulamela. However all tested ecosystem indicators of climate change were significant in Mutale.

\section{Access to climate information}

We examined respondents' access to climate information in order to ascertain effective media for communicating climate information as a means of improving climate change awareness in the study area. Access to climate information via 11 major media source (Newspaper, radio, Meteorological service, TV, Observation, School/teacher, visiting climate scientists/experts, village leader, family and friends) in use in the study area was examined. Results in Table 5 show the top five media sources used to access climate information by respondents. 
TABLE 5 Media as a source of climate information among rural people

\begin{tabular}{lllll}
\hline Information source & Response & \multicolumn{3}{c}{ Proportion of respondents (\%) in } \\
\cline { 3 - 4 } & & $\begin{array}{c}\text { Makhado }(\mathbf{n}= \\
\mathbf{1 5 6})\end{array}$ & $\begin{array}{c}\text { Mutale }(\mathbf{n} \\
\mathbf{= 1 1 0})\end{array}$ & $\begin{array}{c}\text { Thulamela }(\mathbf{n} \\
\mathbf{1 0 0})\end{array}$ \\
\cline { 2 - 4 } & & & \\
\cline { 2 - 4 } Yes & 91.6 & 72.0 & 13 \\
Yes & 98.7 & 100 & 83 \\
Yes & 32.9 & 37.4 & 13 \\
Yes & 81.2 & 97.2 & 15 \\
Yes & 90.9 & 84.3 & 46 \\
\hline
\end{tabular}

Although word of mouth from friends and family was not a popular media for accessing climate information in Thulamela (13.0), it was however a popular source in Makhado (91.6), and Mutale (72.0). Moreover, Pearson chi-square showed that there is a significant difference $(\mathrm{P}=0.000)$ in the use of this media source across the municipalities. Similarly, the use of radio, village head, meteorological service and school teacher as media for accessing climate information was significantly different $(\mathrm{P}<0.05)$ across the municipalities. Radio appears to be the most widely used media source for accessing climate information, reaching up to $100 \%$ of respondents' usage in Mutale.

\section{Perceptions regarding belief in the causes of climate change}

Results in Table 6 show trends in respondents' belief about the causes of climate variability and change. Belief that climate change is a natural phenomenon, caused by natural variation in climatic condition is high in the three locations: Makhado (78.2\%), Mutale (87.3\%), and Thulamela $(73 \%)$. This might be an indicator of high scepticism among rural households about causes and reality of climate change. However, Pearson chi-square test indicates that there was no significant difference $(\mathrm{p}=0.140)$ in this belief across the municipalities. 
TABLE 6 Respondents' perception of causes of climate variability and change

\begin{tabular}{|c|c|c|c|c|}
\hline \multirow[t]{2}{*}{ Causative factor } & \multirow[t]{2}{*}{ Response } & \multicolumn{3}{|c|}{ Proportion of respondents $(\%)$ in } \\
\hline & & $\begin{array}{c}\text { Thulamela } \\
(\mathrm{n}=\mathbf{1 0 0})\end{array}$ & $\begin{array}{c}\text { Makhado } \\
(n=156)\end{array}$ & $\begin{array}{l}\text { Mutale (n } \\
=110)\end{array}$ \\
\hline \multirow[t]{2}{*}{ Anger of the gods } & It is a cause & 28.7 & 45.9 & 14 \\
\hline & $\begin{array}{l}\text { It is not a cause } \\
\text { Don't know }\end{array}$ & $\begin{array}{l}27.4 \\
43.9\end{array}$ & $\begin{array}{l}21.1 \\
33\end{array}$ & $\begin{array}{l}30 \\
56\end{array}$ \\
\hline $\begin{array}{l}\text { Ancestors ways of punishing } \\
\text { our wrong }\end{array}$ & $\begin{array}{l}\text { It is a cause } \\
\text { It is not a cause } \\
\text { Don't know }\end{array}$ & $\begin{array}{l}28.8 \\
26.3 \\
44.9\end{array}$ & $\begin{array}{l}48.2 \\
20 \\
31.8\end{array}$ & $\begin{array}{l}19 \\
30 \\
51\end{array}$ \\
\hline Population growth & $\begin{array}{l}\text { It is a cause } \\
\text { It is not a cause } \\
\text { Don't know }\end{array}$ & $\begin{array}{l}45.5 \\
34.6 \\
19.9\end{array}$ & $\begin{array}{l}88.1 \\
5.5 \\
6.4\end{array}$ & $\begin{array}{l}27 \\
43 \\
30\end{array}$ \\
\hline $\begin{array}{l}\text { Uncontrolled harvest of forest } \\
\text { resources }\end{array}$ & $\begin{array}{l}\text { It is a cause } \\
\text { It is not a cause } \\
\text { Don't know }\end{array}$ & $\begin{array}{l}82.7 \\
9 \\
8.3\end{array}$ & $\begin{array}{l}91.7 \\
4.6 \\
3.7\end{array}$ & $\begin{array}{l}63 \\
20 \\
17\end{array}$ \\
\hline \multirow[t]{2}{*}{ Poor farming practices } & $\begin{array}{l}\text { It is a cause } \\
\text { It is not a cause }\end{array}$ & $\begin{array}{l}72.4 \\
19.2\end{array}$ & $\begin{array}{l}89 \\
5.5\end{array}$ & $\begin{array}{l}68 \\
22\end{array}$ \\
\hline & Don’t know & 8.3 & 5.5 & 10 \\
\hline \multirow{3}{*}{$\begin{array}{l}\text { Natural variations in the } \\
\text { climate }\end{array}$} & It is a cause & 78.2 & 87.3 & 73 \\
\hline & It is not a cause & 13.5 & 7.3 & 16 \\
\hline & Don't know & 8.3 & 5.5 & 11 \\
\hline
\end{tabular}

However, we observed a significant difference $(\mathrm{p}<0.05)$ in the belief that climate change is caused by cultural/spiritual issues such as ancestors anger, anger of the gods, among others across the municipalities. This belief is particularly low in all the municipalities as evidenced in the proportion of respondents in Makhado (26.3\%), Mutale (20.0\%), and Thulamela $(30.0 \%)$ who believed climate change were as a result of punishment from ancestral spirits as a cause of climate change. This notwithstanding, belief in anthropogenic causes of climate change was high in the study communities as evidenced in the proportion of respondents in Makhado (82.7\%), Mutale (91.7\%), and Thulamela (63.0\%) that believed that climate change is caused by uncontrolled harvest of forest resources. Additionally, there was strong belief among respondents in Makhado (72.4\%), Mutale (89.0\%), and Thulamela $(68.0 \%)$ that climate change is caused by poor farming practices. Belief in anthropogenic causes of climate change was also observed to differ significantly $(\mathrm{P}<0.05)$ across the municipalities. 
We then explore factors that influence belief in the causes of climate change. The results of the logit regression analysis are presented in table 7.

TABLE 7 Factors influencing belief in causes of climate change

\begin{tabular}{|c|c|c|c|}
\hline Belief & Factors & Estimate & Significance \\
\hline \multirow[t]{3}{*}{ Natural Phenomenon } & Gender (female) & -0.4877 & $*$ \\
\hline & $\begin{array}{l}\text { Concern about increase in energy cost as a result of } \\
\text { climate change }\end{array}$ & 0.8103 & $*$ \\
\hline & Possession of livestock keeping skills & 0.3910 & $*$ \\
\hline \multirow{4}{*}{$\begin{array}{l}\text { Anthropogenic } \\
\text { causes }\end{array}$} & Gender (female) & -0.9793 & $*$ \\
\hline & $\begin{array}{l}\text { Willingness to stop unregulated harvest of forest } \\
\text { resources }\end{array}$ & 0.4307 & $*$ \\
\hline & $\begin{array}{l}\text { Concern about shift in planting season as a result of } \\
\text { climate change }\end{array}$ & 0.8925 & $*$ \\
\hline & Possession of carpentry skill & -2.0789 & $* *$ \\
\hline \multirow{3}{*}{$\begin{array}{l}\text { Cultural/spiritual } \\
\text { causes }\end{array}$} & Concern about climate change effect on public health & -0.8889 & $*$ \\
\hline & Possession of farming skill & 0.3149 & $*$ \\
\hline & Possession of livestock keeping skills & 0.5222 & $* * *$ \\
\hline
\end{tabular}

The result in Table 7 showed that possession of farming and livestock keeping skills increases the likelihood that a respondent will associate causes of climate change with cultural/or spiritual believes. Similarly, concern about shift in planting season as a result of climate change, and willingness to embrace controlled harvest of forest resources in response to climate change effect increases the likelihood that a respondent will believe in anthropogenic causes of climate change. However, gender with reference to female, decreases the likelihood that a respondent will associate climate change with natural phenomenon. There was however a correlation between belief that climate change is caused by cultural/spiritual issues and belief that climate change is a natural phenomenon as both beliefs are significantly influenced by a common factor; possession of livestock keeping skills. 


\section{Concern about climate change}

Concern of the people with regard to effect of climate change on lives and livelihood was explored. The results in table 8 revealed that majority of the respondents were concerned about climate change and its impact on their lives and livelihoods. More than $90 \%$ of all respondents were strongly concerned about direct and indirect effect of climate change on availability of water, public health, and food availability.

TABLE 8 Concern about climate change impact and consequences

\begin{tabular}{|c|c|c|c|c|}
\hline \multirow[t]{2}{*}{ Concerns } & \multirow[t]{2}{*}{ Response } & \multicolumn{3}{|c|}{ Proportion of respondents $(\%)$ in } \\
\hline & & $\begin{array}{c}\text { Thulamela } \\
(\mathrm{n}=100)\end{array}$ & $\begin{array}{c}\text { Thulamela } \\
(n=100)\end{array}$ & $\begin{array}{c}\text { Thulamela }(\mathrm{n} \\
=100)\end{array}$ \\
\hline Damage to forest resources & Not at all & 9 & 7.3 & 6.9 \\
\hline & $\begin{array}{l}\text { Less concerned } \\
\text { Strongly concerned }\end{array}$ & $\begin{array}{l}7.7 \\
83.3\end{array}$ & $\begin{array}{l}6.4 \\
86.4\end{array}$ & $\begin{array}{l}1.0 \\
92.1\end{array}$ \\
\hline Increase food cost & $\begin{array}{l}\text { Not at all } \\
\text { Less concerned } \\
\text { Strongly concerned }\end{array}$ & $\begin{array}{l}1.3 \\
3.2 \\
95.5\end{array}$ & $\begin{array}{l}4.5 \\
0.9 \\
94.5\end{array}$ & $\begin{array}{l}1.0 \\
1.0 \\
98\end{array}$ \\
\hline Danger to public health & $\begin{array}{l}\text { Not at all } \\
\text { Less concerned } \\
\text { Strongly concerned }\end{array}$ & $\begin{array}{l}1.3 \\
1.3 \\
97.4\end{array}$ & $\begin{array}{l}2.8 \\
0.0 \\
97.2\end{array}$ & $\begin{array}{l}2 \\
0.0 \\
98\end{array}$ \\
\hline Reduce water availability & $\begin{array}{l}\text { Not at all } \\
\text { Less concerned } \\
\text { Strongly concerned }\end{array}$ & $\begin{array}{l}0.6 \\
1.3 \\
98.1\end{array}$ & $\begin{array}{l}2.8 \\
0.0 \\
96.3\end{array}$ & $\begin{array}{l}4 \\
0.0 \\
96\end{array}$ \\
\hline Shift in planting season & $\begin{array}{l}\text { Not at all } \\
\text { Less concerned } \\
\text { Strongly concerned }\end{array}$ & $\begin{array}{l}2.5 \\
7.6 \\
89.8\end{array}$ & $\begin{array}{l}3.6 \\
7.3 \\
89.1\end{array}$ & $\begin{array}{l}8 \\
7 \\
85.0\end{array}$ \\
\hline
\end{tabular}

Majority of respondents in Makhado (83.3), Mutale (86.4), and Thulamela (92.1) were strongly concerned about climate change effect on forests and forest resources. There were also few respondents who were not at all concerned about climate change effect on forest resources. Pearson chi-square test shows that there was no significant difference $(p=0.182)$ in concern about climate change effect on forest resources across the municipalities. Thus there was a strong concern about climate change effect on forest resources across the municipalities. We equally observed a strong concern about climate 
change effect on water availability, public health, food cost, and planting season across the municipalities.

\section{Willingness to adopt intervention measures for climate change}

Results in Table 9 shows that majority of respondents in all the study villages are willing to embrace several types of behavioural change towards responsible forest use and management in contributing to collective sustainable forest management as a strategy towards improving lives and livelihood resilience to climate change. More than $60 \%$ of respondents in all the study communities either agreed or strongly agreed that their adoption of responsible behaviour such as; stop unregulated harvest of forest resources, accepts training on good forest exploitation practices, planting more trees on farms, use of alternative cooking energy

TABLE 9 Behaviour change for collective climate change management

\begin{tabular}{|c|c|c|c|c|}
\hline \multirow[t]{2}{*}{ Behaviour change } & \multirow[t]{2}{*}{ Response } & \multicolumn{3}{|c|}{ Proportion of respondents $(\%)$ in } \\
\hline & & $\begin{array}{c}\text { Thulamela } \\
(\mathrm{n}=\mathbf{1 0 0})\end{array}$ & $\begin{array}{c}\text { Thulamela } \\
(n=100)\end{array}$ & $\begin{array}{c}\text { Thulamela }(\mathrm{n} \\
=100)\end{array}$ \\
\hline \multirow{4}{*}{$\begin{array}{l}\text { Stop unregulated harvest of } \\
\text { forest resources }\end{array}$} & Strongly agree & 17.3 & 94.5 & 30 \\
\hline & $\begin{array}{l}\text { Agree } \\
\text { Neither agree nor disagree }\end{array}$ & $\begin{array}{l}49.4 \\
0.6\end{array}$ & $\begin{array}{l}2.8 \\
0.0\end{array}$ & $\begin{array}{l}44 \\
2\end{array}$ \\
\hline & Disagree & 23.7 & 1.8 & 20 \\
\hline & Strongly disagree & 9 & 0.9 & 4 \\
\hline \multirow{5}{*}{$\begin{array}{l}\text { Accepts training on good forest } \\
\text { exploitation practices }\end{array}$} & Strongly agree & 20.9 & 0.9 & 37 \\
\hline & Agree & 70.9 & 96.4 & 59 \\
\hline & Neither agree nor disagree & 2.5 & 2.7 & 1 \\
\hline & Disagree & 4.4 & 0.0 & 1 \\
\hline & Strongly disagree & 0.6 & 0.0 & 2. \\
\hline \multirow{4}{*}{$\begin{array}{l}\text { Willing to use alternative } \\
\text { cooking energy other than } \\
\text { firewood and charcoal }\end{array}$} & Strongly agree & 7.6 & 78.2 & 25.3 \\
\hline & Agree & 54.1 & 1.8 & 58.6 \\
\hline & Neither agree nor disagree & 5.7 & 0.9 & 1.0 \\
\hline & Disagree & 27.4 & 15.5 & 10.1 \\
\hline \multirow{5}{*}{$\begin{array}{l}\text { Willing to plant more trees on } \\
\text { farms }\end{array}$} & Strongly disagree & 5.1 & 3.6 & 5.1 \\
\hline & Strongly agree & 24.4 & 92.7 & 31.0 \\
\hline & Agree & 69.9 & 4.5 & 60.0 \\
\hline & Neither agree nor disagree & 1.3 & 0.0 & 0.0 \\
\hline & Disagree & 3.8 & 0.0 & 6 \\
\hline \multirow{6}{*}{$\begin{array}{l}\text { Willing to diversify income by } \\
\text { learning how to cultivate } \\
\text { NTFPs such as beekeeping, } \\
\text { mushroom production }\end{array}$} & Strongly disagree & 0.6 & 2.7 & 3 \\
\hline & Strongly agree & 12.2 & 61.8 & 28 \\
\hline & Agree & 66.7 & 0.9 & 49 \\
\hline & Neither agree nor disagree & 8.3 & 1.8 & 1.0 \\
\hline & Disagree & 11.5 & 20 & 16 \\
\hline & Strongly disagree & 1.3 & 15.5 & 6 \\
\hline
\end{tabular}


other than firewood and charcoal, and diversification of income by learning how to cultivate

NTFPs such as beekeeping, mushroom production, will contribute positively towards execution of effective forest based climate change intervention measure in their community.

There is a strong agreement by respondents in all the study communities to accept the behavioural change as a way of participating towards collective effort of improving live and livelihood resilience to climate variability and change in the study communities.

\section{DISCUSSION}

\section{Awareness}

Disproportionate level of awareness of the term climate change as observed in this study communities is a common trend in Africa. For instance, Nzeadibe et al. (2013) reported that over $60 \%$ of respondents in the Niger-Delta region of Nigeria knew little or nothing about climate change. Cyprian et al. (2013) reported a high level of awareness (71.7\%) of the term climate change among rural dwellers in Cross River state, Nigeria. This trend highlights the need for more enlightenment campaign to ensure high level of awareness of climate change among the rural population in Vhembe District. High level of awareness observed in Thulamela showed that efforts being made were producing positive results, but intensification is needed across all municipalities. Poor level of awareness of the specific term 'climate change' in Mutale and Makhado can hinder the people's meaningful participation in climate change intervention programmes, which may result in increased vulnerability to climate change. As Gbetibouo (2009) and Maddison (2007) observed, the awareness of climate change presents an opportunity to reduce vulnerability. There is therefore need to improve climate change communication effort in the study area. 
Despite poor awareness of the term "climate change" in majority of study area, there is however a high level of perception of changes in climatic event. Erratic rainfall, flood incidence, extreme temperature, and drought are some of the climatic events that respondents have observed to be showing high variability. Cyprian et al. (2014) also reported similar observation in climatic event in Nigeria. Aside from perception of changes in climatic events, respondents also perceived changes in onset and offset of seasons. Rural people have been observed to be able to perceive changes in onset and offset of seasons in their locality (Kalinda 2011). This indicates that although rural people may not be aware of the term climate change, they are however aware of climate variability and extreme weather events occurring in their locality. Thus linking climate information with prevailing extreme weather event occurring in the locality can be an effective means of improving climate change awareness in the community.

Furthermore, significant high level of ecosystem indicators of climate change observed in the study area indicates the likelihood that climate change induced environmental change occurrence in the area. Similar trends have been observed by Nesha et al. (2014) where $43 \%$ and $59 \%$ of respondents, respectively reported to have observed disappearance of species and environmental degradation. However, it is difficult to say for certain that these observed ecosystem indicators of climate change in the study area are solely as a result of climate change.

The study further shows that having no qualification decreased the likelihood that a respondent will be aware of the term climate change or perceive variability in climatic events. On the other hand, having farming skills was found to improve the likelihood that a respondent will be aware of or perceive changes in climatic event. This line of thinking is also supported by the findings of Apata et al. (2009), and Gbetibouo (2009), where farmers were observed to have higher level of perception of changes in their environment. 
Observed factors influencing perceptions and awareness of climate change suggests that perceptions are influenced by respondent's educational and socioeconomic profile. Efforts to improve climate change awareness in the study communities will hence be effective if climate change information communications are designed to suit the people's educational and socioeconomic profile so as to improve their chance of understanding and associating with such climate information in improving climate change awareness in the area. Grounding climate change information dissemination approach on experiences which the people can understand in a local and personal context, particularly in relation to their livelihood activities will thus be a welcome strategy. Information based solely on the science, nature and causes of climate change, is unlikely to improve the people understanding, awareness and perception of climate change.

\section{Access to climate information}

The top five media source popularly used by people in the study communities to access climate information can play a significant role in improving climate change awareness in the study area. Timely access to climate information is indeed a key component of adaptation planning. As observed by Wiid and Ziervogel (2012), access to climate information improved farmers' productivity compared to those farmers that relied on past climate experiences. Incorporation of village head and chiefs in climate change awareness programme can be an important strategy for improving climate change awareness through improved access to information; given the communities' leadership structure and the significant role played by chiefs and village head in maintaining peace and order in the communities.

Overall, an integrated approach that utilises these entire media source simultaneously can be an effective means of improving climate change communication in the area. This implies that policymakers and relevant stakeholders who address climate change in the area can make full use of various media channels to disseminate information to the rural people. In 
addition, new media source for real time delivery of climate information for efficient and effective delivery of warning and information on climate issues to improve climate change awareness, and increase adaptive capacity by better preparing community members to cope with climate change can be explored. In this regard, dissemination of real time climate information via mobile phone is a media worth exploring.

\section{Perceptions regarding belief in the causes of climate change}

High level of belief in perception that climate change is a natural phenomenon, caused by natural variation in climatic condition might be an indicator of high scepticism among rural household about causes and reality of climate change. Scepticism about reality of climate change among rural households is not entirely strange. Capstick (2012), Marsden et al (2009), and Lorenzoni and Langford (2001) in their studies on public perception of climate change in Australia and UK respectively observed high scepticism among the public about the causes and reality of climate change. Scepticism has obvious implication for climate change intervention measures in the area. Climate change intervention may be tough to sell to sceptics (Roderick 2012). The cause of this scepticism is difficult to ascertain as there remains little published peer reviewed research that has explored how rural forest based communities in South Africa conceptualise climate change. Nevertheless, the finding of high scepticism among rural households in the study area speaks to the need to educate rural people on the concept and causes of climate change. There was also few proportion of respondent in the study communities who perceived cultural issues such as punishment from ancestral spirits as a cause of climate change. A similar trend has been observed by Cyprian et al (2014) where negligible (4.7\%) proportion of respondents perceived supernatural power to be the cause of climate variability and change. People with this type of belief may be difficult to convince to participate in climate change intervention initiatives. 
Although scepticism about cause and reality of climate change is high in the study area, equally high is the belief in anthropogenic causes of climate change. Strong belief in anthropogenic causes of climate change has also been observed by Dube and Phiri (2013), and Cyprian et al (2014) among rural people in Africa. Belief in anthropogenic activities as a cause of climate change is a strong indicator of belief in the reality of climate change in the study area, and a good indicator of possible public acceptance of climate change intervention measures in the area. The challenge for development official in the study communities will therefore be how to convince both sceptics and believers in the reality of climate change to cooperate and participate productively in climate change intervention initiatives in the community.

\section{Concern about climate change}

Observed strong concern about climate change effect on forest resources, public health, water etc. among respondents in the study communities is consistent with what has been observed elsewhere. Duan and $\mathrm{Hu}$ (2014) reported that $77.6 \%$ of respondents in northern China were concerned about climate change impact on water availability. In the same vein, Spence et al (2010) in a study about public perception of climate change and energy future in Britain reported that over two-thirds $(71 \%)$ of respondents were either 'very concerned' $(28 \%)$ or 'fairly concerned' (43\%) about climate change impact on energy.

Theoretically, strong concern about climate change impact on forest resources may indicate that rural people in South Africa would readily embrace forest based climate change adaptation and mitigation programme. Concern about climate change impact on forest resources is more likely to influence the people to participate actively in participatory forest management and embrace responsible behaviour towards forest exploitation and use. As observed by Ameur et al (2001), behavioural change towards responsible forest based livelihood practices is primarily driven by level of concern about climate change effect and 
consequences, with individuals striking a personal balance between these factors. The challenge for local authorities therefore would be how to translate the people's concern about climate change effect on forest resources into improved rural people participation and ownership in forest management practices.

Although people's awareness and perceived importance of environmental issues do not always translate into actions to change behaviour (Lonrenzoni and Langford 2001), evidence from this study however shows a general strong will to change behaviour in favour of mitigation efforts in managing climate change challenge. We thus believed that if people are informed about climate change challenges and its effect on forests, responsible behavioural change towards responsible forest use and management may be realised. As observed by Ajzen (1991), people's intentions towards responsible forest use and management can be inspired by their beliefs, attitudes, and knowledge and understandings of climate change issues. Translating the people's expressed behavioural change towards responsible forest use and management into action, and mobilizing the people to meaningfully participate in participatory forest management will thus be essential for climate change intervention programmes in the area.

\section{CONCLUSIONS AND RECOMMENDATIONS}

This paper has examined the understanding of climate change and associated extreme weather events in the context of awareness and attitude from the perspective of forest based rural communities in South Africa. Although awareness of the specific term climate change is generally low in Mutale and Makhado municipalities, but high in Thulamela, majority of community members expressed high level of awareness of issues and challenges of climate change and extreme weather events. Nevertheless, widespread awareness and acceptance may not necessarily translate to readily widespread engagement with climate change. As was 
observed in the study, belief in both anthropogenic causes and natural phenomenon causes of climate change is high in the study area. This might pose a challenge when mobilising both believers in reality of climate change and sceptics within a community for collective participation in climate change intervention programmes. In general, there is a widespread concern about climate change effect on lives and livelihood. We therefore recommend, use of multiple media source and association of climate information with the people's livelihood activities as a strategy for improving climate change awareness, addressing the people's concern and promoting peoples' engagement in climate change intervention measures in the study communities.

\section{REFERENCES}

AKOMPAB DA, BI P, WILLIAMS S, GRANT J, WALKER IA, AUGOUSTINOS M. 2013. Awareness of and Attitudes towards Heat Waves within the Context of Climate Change among a Cohort of Residents in Adelaide, Australia. Int. J. Environ. Res. Public Health,10: 117; doi:10.3390/ijerph10010001

AJZEN I. 1991. The theory of planned behavior. Organizational Behavior and Human Decision Processes, 50, 179-211

AMEUR, B. M., SALAH, G., AND HAMED, D. (2001). Analyzing forest users' destructive behavior in Northern Tunisia. Land Use Policy, 18: 153-163.

APATA TG, SAMUEL KD, ADEOLA AO. 2009. Analysis of Climate Change Perception and Adaptation among Arable Food Crop Farmers in South Western Nigeria. International Association of Agricultural Economists' 2009 Conference, Beijing, China, August 16-22,209 (pp. 1-15). Beijing: JEL Classification.

BETHLEHEM J. 2015. Applied Survey Methods: A statistical perspective. Retrieved March 11, 2015, from Weighting adjustment: http://www.applied-survey-methods.com/weight.html 
BERG, R. G. 2014. 4.1.1. SPSS Binomial Test. Retrieved June 18, 2015, from SPSS Tutorials: The Ultimate Guide for Mastering SPSS: http://www.spss-tutorials.com/spss-binomial-test/

BHUSAL Y.2009. Local Peoples' Perceptions on Climate Change, Its Impacts and Adaptation Measures in Mid-Mountain Region of Nepal (A Case study from Kaski District). Pokhara, Nepal.: B.Sc. Forestry Research Thesis Submitted to Tribhubhan University, Institute of Forestry, Pokhara, Nepal.

BLESS C, SMITH CH .1995.Fundamentals of social research methods: An African perspective $2^{\text {nd }}$ edition. Juta and Co, Ltd South Africa:50-78.

BRYAN E, DERESSA TT, GBETIBOUO GA, RINGLER C .2009. Adaptation to climate change in Ethiopia and South Africa: options and constraints. Environ Sci Policy 12:413-426

BUYS L, MILLER E, MEGEN K .2012. Conceptualising climate change in rural Australia: Community perceptions, attitudes and (in)actions. Regional Environmental Change, 12(1): 237-248.

CAPSTICK SB .2012. Climate change discourses in use by the UK public: commonalities and variations over a fifteen year period. Doctor of Philosophy thesis submitted to School of Psychology Cardiff University.

CHAMBERLAIN D, ESSOP H, HOUGAARD C, MALHERBE S, WALKER R. 2005. Part I: The contribution, costs and development opportunities of the Forestry, Timber, Pulp and Paper industries in South Africa. Final report - 29 June 2005. Genesis Analytics (Pty) Ltd. South Africa.

CHRISTENSEN JH, HEWITSON B, BUSUIOC A, CHEN A, GAO X, HELD I, JONES R, KOLLI RK, KWON WT, LAPRISE R, MAGAN`A RUEDA V, MEARNS L, MENE`NDEZ CG, RA“ISA“NEN J, RINKE A, SARR A, WHETTON P .2007. Regional climate projections. In: Solomon S, Qin D, Manning M, Chen Z, Marquis M, Averyt KB, Tignor M, Miller HL (eds) 
Climate Change 2007: the physical science basis. Contribution of Working Group I to the

Fourth Assessment Report of the Intergovernmental Panel on Climate Change. Cambridge University Press, Cambridge, UK: 847-940

CLEWER AG, Scarisbrick DH. 2001. Practical statistics and experimental design for plant and crop science. John Wiley \& Sons, Ltd. West Sussex England:1-22.

CORNER A, MARKOWITZ E, PIDGEON N .2014. Public engagement with climate change: the role of human values. WIREs Clim Change, 5:411-422; DOI: 10.1002/wcc.269

CYPRIAN A, EGBE, MARGARET AY, ASUQUO EO, FRANCIS EB. 2014. Rural Peoples' Perception to Climate Variability/Change in Cross River State-Nigeria . Journal of Sustainable Development, 7( 2): 25-36.

DUBE T, PHIRI K. 2013. Rural Livelihoods under Stress: The Impact of Climate Change on Livelihoods in South Western Zimbabwe. American International Journal of Contemporary Research, 3 (5): 11-25.

DUAN H, HU Q. 2014. Local officials' concerns of climate change issues in China: a case from Jiangsu. Journal of Cleaner Production, 6(4): 545-551

GANDURE S, WALKER S, BOTHA JJ .2013. Farmers' perceptions of adaptation to climate change and water stress in a South African rural community. Environmental Development 5: 39-53

GBETIBOUO GA .2009. Understanding Farmers' Perceptions and Adaptations to Climate Change and Variability: The Case of the Limpopo Basin,South Africa. Washington, DC:: IFPRI Discussion Paper.

HAM C, THERON F .2001. Community forestry resource: a case study of selected woodlots in the Eastern Cape Province. Southern African Forestry Journal. 191: 65-74. 
HARRELL FE. 2001. Regression Modeling Strategies. Springer-Verlag. ISBN 0-387-95232-2. Intergovernmental Panel on Climate Change (IPCC). Climate Change 2007 - Impacts, Adaptation and Vulnerability Contribution of Working Group II to the Fourth Assessment Report of the IPCC (978 0521 88010-7 Hardback; 9780521 70597-4 Paperback)

ISHAYA S, ABAJE IB. 2008. Indigenous people's perception on climate change and adaptation strategies in Jema'a local government area of Kaduna State, Nigeria. Journal of Geography and Regional Planning, 1(8): 138-143.

KADIR T, MAZUR L, MILANES C, RANDLES K. 2013. Indicators of climate change in California. California: California Environmental Protection Agency.

KALINDA TH. 2011. Smallholder Farmers' Perceptions of Climate Change and Conservation Agriculture: Evidence from Zambia. Journal of Sustainable Development, 4(4): 73-85.

LORENZONI I, LANGFORD I. 2001. Climate change now and in the future: A mixed methodological study of public perceptions in Norwich (UK) CSERGE Working Paper ECM 01-05 Norwich, UK.

MACHARIA PN, LUGADIRU J, WAKORI S, NG'ANG'A LW, THURANIRA E. 2011. Perceptions and adaptation measures to climate change and variability by immigrant communities in semi-arid regions of nyeri north and laikipia east districts. Kenya Forestry Research Institute: 1034-1042.

MADDISON D .2007. The Perception of and Adaptation to Climate Change in Africa. The World Bank Development Research Group Policy Research Working Paper 4308: 1-53.

MARSDEN G, JOPSON A, HARWATT H, KIMBLE M. 2009. Better Informed, Better Behaved? Public Attitudes to Climate Change and Transport: Empirical Findings from England. In: UNSPECIFIED. Transportation Research Board (TRB) 88th annual meeting 11-15 January (pp. 1-18). Washington DC: White Rose Research Online. 
MENGISTU DK. 2011. Farmers' perception and knowledge of climate change and their coping strategies to the related hazards: Case study from Adiha, central Tigray, Ethiopia. Agricultural Sciences: 138-145.

MERTZ O, MBOW C, REENBERG A, DIOUF A. 2009. Farmers' perceptions of climate change and agricultural adaptation strategies in rural Sahel. Environmental Management, 43: 804-816.

NATIONAL PLANNING COMMISSION: NPC .2011. National development plan 2030: our future makes it work. Pretoria. ISBN: 978-0-621-41180-5

NESHA K, RAHMAN A, HASAN K, AHMED Z. 2014. People's Perception in relation to Climate Change and its Adverse Effects in Rural Bangladesh. Journal of environment and human, 1(3): 23-33.

NZEADIBE TC, EGBULE CL, CHUKWUONE NA, AND AGU VC .2013. Climate Change Awareness and Adaptation in the Niger Delta Region of Nigeria. Nairobi: African Technology Policy Studies Network, WORKING PAPER SERIES | No. 57.

OFOEGBU C. 2014. The contribution of tree plantation to household welfare: case study of Piet Retief and Iswepe communities. International Forestry Review, 16 (2): 172-179

PIYA L, MAHARJAN KL, JOSHI NIRAJ P. 2012. Perceptions and Realities of Climate Change among the Chepang Communities in Rural Mid-Hills of Nepal. Journal of Contemporary India Studies: Space and Society, Hiroshima Universit,. 2: 35-50.

RIK T, ALLAN C, NICKI M, DIGBY R. 2008. Understanding rural landholder responses to climate change. Institute for Land, Water \& Society. Charles Sturt University. Report No. 48: 1-85.

RODERICK MR. 2012. Farmer Perceptions and Beliefs about Climate Change: A North Carolina Perspective. North Carolina: North Carolina Cooperative Extension Services; Agriculture and Resource Economics. 
STATISTICS SOUTH AFRICA: STAT SA. 2012. Census 2011, Statistical release - P0301.4 /

Statistics South Africa. Pretoria

SWANEPOEL H, BEER F .2006. Community Development: Breaking the cycle of poverty, $4^{\text {th }}$ edition. Juta and Co, Ltd South Africa: 350- 400.

TURPIE J, AND VISSER M. 2013. The impact of climate change on South Africa's rural areas. In F. A. Commission, Submission for the 2013/14 Division of Revenue (pp. 100-162). Cape Town: Financial and Fiscal Commission.

TURPIE J, WINKLER H, SPALDING-FECHER R, MIDGLEY G. 2002. Economic Impacts of Climate Change in South Africa: A Preliminary Analysis of Unmitigated Damage Costs . Cape Town: Southern Waters and Energy \& Development Research Centre.

VHEMBE D. 2013. Vhembe District Municipality Profile. Pretoria: Cooperative Governance and Traditional Affairs.

WEINGART P, ENGELS A, PANSEGRAU P. 2000. Risks of communication: discourses on climate change in science, politics, and the mass media. Public Understanding of Science, 9: 261-283.

WIID N, ZIERVOGEL G. 2012. Adapting to climate change in South Africa: commercial farmers' perception of and response to changing climate. South African Geographical Journal, 94(2): $152-173$.

WOLF J, MOSER SC .2011. Individual understandings, perceptions, and engagement with climate change: insights from in-depth studies across the world. WIREs Clim Change, 1-23: DOI: $10.1002 / w c c .120$

WOLFSEGGER C. 2005. Perception and Adaptation to Climate Change in Low Altitude Ski Resorts in Austria. Lund, Sweden: Lund University Master's Programme in International Environmental Science. 